\title{
Design, implementation and operation of a solar hybrid system in a remote area in the Colombian Guajira desert
}

\author{
L. Rodríguez Urrego ${ }^{1}, \mathrm{~J}_{\text {. Valencia Llanos }}^{2}$, D. Rodríguez Urrego ${ }^{3}$ \\ \& A. Martínez Garcia ${ }^{1}$ \\ ${ }^{1}$ EAN University, Colombia \\ ${ }^{2}$ Institute of Planning and Promotion of Energy Solutions \\ for Non-interconnected Areas (IPSE), Colombia \\ ${ }^{3}$ Piloto University, Colombia
}

\begin{abstract}
This paper presents one of the most important and representative projects in the country concerning isolated energy systems. The Institute of Planning and Promotion of Energy Solutions (IPSE) conducted this project for noninterconnected zones under the Ministry of Mines and Energy of Colombia. This project targets two main objectives: To increase the hours of electricity supply to the population and reduce the hours of use of diesel plants. This project allows for the production of electricity from solar radiation through "preinstalled solar trackers $-100 \mathrm{kWp}$ installed power" and a new solar farm which supplies $220 \mathrm{kWp}$, plus a battery room with 480 cells and installed capacity storage $3,148 \mathrm{kWh}$. Finally, the facility has been supported by two $308 \mathrm{~kW}$ diesel plants.

This paper presents the largest PV system isolated from Colombia so far. First, we make a geographical description of the area of project implementation, also an approach to the indigenous community, their customs and their social and technological issues. Likewise, the paper presents some of the challenges and difficulties of setting up the project in an isolated area of difficult access and complex environmental conditions. In addition, the stages of assembly and some technical details of installation are presented, highlighting the design features and implementation with respect to civil works, electrical works and the main
\end{abstract}


characteristics of the photovoltaic system in terms of panels, batteries and system integration.

Keywords: isolated hybrid energy system, storage system, Colombian Guajira, renewable energy.

\section{Introduction}

Currently, it is estimated that globally photovoltaic (PV) technology installations provide $200 \mathrm{GWp}$ of power [1], of which about $15 \%$ are located in isolated and remote areas of the world. According to GTM Research report [2], Latin America and the Caribbean will install more than $625 \mathrm{MW}$ of grid-connected PV in 2014 , corresponding to a $370 \%$ increase in the annual growth of the continent compared to 2013. It is expected that the value will triple in 2015 with 2.1 gigawatts of PV. Chile leads the region in PV systems in 2014, with over three-quarters of the total in Latin America. On the other hand, in Colombia, things have been moving slowly in these technologies, the electricity sector in Colombia is dominated by hydroelectric power (70-75\%). The great potential in new renewable energy technologies, such as wind, solar and biomass, has a production quota of only $1-3 \%$, consisting mainly of wind power. The country has significant resources in such renewable technologies that remain largely untapped. Electricity demand is growing by about 4\% annually, so is highly correlated with GDP trends, with quotas for sectors ranging from residential $42 \%$, industrial $32 \%$, and commercial $18 \%$. In regulation topics, last year the president signed the 1715 Law [3] with great advantages for the country, as discussed in section 4 and which currently governs the Regulatory Commission of Energy and Gas (CREG) [4]. Alternative energies in Colombia are considered in this law as a matter of public and social interest and national convenience implying not only to find more efficient systems responsible for the environment, but also to be able to meet the needs of all Colombians, especially isolated communities in the capital.

\section{Characteristics of the Guajira Department}

The department consists of the Massif "Guajiro" northeast, an ancient area located on the peninsula of La Guajira and comprising the mountains of "Jarara Cocinas" "Carpintero" and "la Makuira"; the latter has the highest elevation reaches "Palúa hill" with $865 \mathrm{~m}$ in this area where the populations are Nazareth and Puerto Estrella. Its landscapes are very beautiful yet rugged for its vast desert areas and large beaches; their customs, many of which were inherited from the Wayuu ethnic group, make the Guajira in general a land full of magic and color for their religious, political, and craft traditions.

\subsection{The communities of Nazareth and Puerto Estrella}

The department is divided into four indigenous territories, and forty-four districts grouped in fifteen municipalities, each administered by their corresponding 
government offices. These municipalities were created by the Departmental Assembly of La Guajira through ordinances issued between 1995 and 2000. Among the townships are Nazareth and Puerto Estrella in the municipality of Uribia, who are the beneficiaries of this project, where people mostly belong to the Wayuu indigenous community. This township had a public service energy produced by two diesel plants that provide about four or five hours of power, intangible to the major cities of the country but a precious commodity in these localities. Being in Nazareth, the home of the installation, is like being in an oasis of contradictions; 7 hours' drive from Uribia, in the desert, an hour from the sea, but guarded by the Mountains of Macuira. The traditional Wayuu culture has a need to guarantee minimum living conditions for the community. Nazareth has a hospital, a police station, a boarding school, a radio station and a few homes or villages where the project will benefit from the solar electric service. In these villages there are hundreds of people waiting to participate actively in the world in order to enjoy simple things such as preserving food, studying, and listening to the radio or just reading a book.

\subsection{The electric energy potential}

The potential of wind energy and radiation of the Department of La Guajira is the most important in the country due to several factors, including the trade winds blowing across the Guajira peninsula from the Caribbean Sea to the northeast towards the southwest and the second, the high levels of radiation by its special location and climate of xerophytic savanna to the south and west and arid or semi-arid steppe north and east, making it the driest area of Colombia. Winds from the Guajira are above $9 \mathrm{~m} / \mathrm{s}$ and daily radiation fluctuates from $6 \mathrm{kWh} / \mathrm{m}^{2}$. By estimating the average annual irradiation of $2059 \mathrm{kWh} / \mathrm{m}^{2}$ with an average annual temperature of $26.9^{\circ} \mathrm{C} \mathrm{[5]} \mathrm{and} \mathrm{maximum} \mathrm{temperatures} \mathrm{up} \mathrm{to}$ $45^{\circ} \mathrm{C}$. Using the "pvPlanner" of SOLARGIS [6] as a simulator of an example of production must be for an installed capacity of $1 \mathrm{kWp}$, an average annual electricity production of $1561 \mathrm{kWh}$ is obtained with a yield of $75.8 \%$; DC/AC losses of $7 \%$ and an availability of $99 \%$ of the PV system. This data makes this department the best area for the production of wind and PV solar alternative energies which compete in this work.

\section{Isolated photovoltaic systems in Colombia}

The (IPSE), under the Ministry of Mines and Energy, is responsible for improving the living conditions of communities, through the identification, development and promotion of projects to bring energy to the localities that do not have it or where provision of the service is poor [7].

\subsection{IPSE projects}

Some of the projects developed by the IPSE has been in operation in the town of "Titumate" located in the department of Choco since 2013. The solar-diesel hybrid system delivers $115 \mathrm{~kW}$ and power supplies 24 hours a day to a population 
of about 600 habitants living in 90 houses. The operation is monitored by a satellite tracking system.

In "Isla Fuerte" located on the continental shelf of the Caribbean in the department of Bolivar a "solar-LPG (liquefied petroleum gas)" hybrid system that delivers $300 \mathrm{~kW}$ was implemented. This currently benefits "2000 people of African descent", a school, a health center and some tourist cabins. This operation is also monitored by a satellite telemetry system. Currently, the system is implemented and consists of 600 panels $(250 \mathrm{Wp}=40 \mathrm{kWp})$, divided into 24 strings of 25 panels, and 18 batteries with a capacity of $3041 \mathrm{kWh}$.

In "Santa Cruz del Islote" is a small island located in the Gulf of Morrosquillo in the department of Sucre with a high population density where 1247 people live in 1 hectare. In 2001, a diesel system that provides $250 \mathrm{~kW}$ and which fails to meet the consumption of villagers currently installed. On this island a project for the production of solar PV runs alongside a system to measure the potential for wind and solar power. Today the system is implemented and consists of 160 panels $(250 \mathrm{Wp}=40 \mathrm{kWp})$, divided into 8 strings of 20 panels, and 6 batteries with a capacity of $1163.5 \mathrm{kWh}$.

In the "Isla Múcura", in the department of Bolivar, a system consisting of 120 panels $(250 \mathrm{Wp}=40 \mathrm{kWp})$, distributed in 6 strings of 20 panels and a battery capacity of $499.2 \mathrm{kWh}$ was designed. This solar-diesel hybrid system is currently being implemented for the benefit of 40 families with a population of 70 children living in poverty.

Finally, the project is located in Upper Guajira - Nazareth and Puerto Estrella - which is in operation today; a detailed description will be given later in this paper.

\section{Law 1715 for the regulation and integration of non-conventional renewable energy}

The main purpose of the 1715 Law signed on May 13, 2014 and which currently governs the Regulatory Commission of Energy and Gas (CREG) is to promote the development and use of "non-conventional sources of energy", especially those from renewable sources, in the Colombian energy system [3]. The idea is the integration into the electricity market and participation in non-interconnected zones and other energy uses as means necessary for sustainable economic development. It also seeks to reduce greenhouse gas and ensure security of the energy supply. With the same purpose it seeks to promote efficient energy management, comprising both energy efficiency and demand response.

To promote each and every one of these goals, the law incentivizes a series of elements that allow both natural persons and public and private companies to invest in this technology. 


\subsection{Promotion of self-generation: large and small-scale and distributed generation}

The government will promote self-generation through the ability to deliver their surplus to a distribution grid and/or transportation. For the small-scale selfgenerated, the surplus to be delivered to the distribution grid is recognized by a bidirectional measurement scheme, including energy credits, according to the rules that CREG has set for that purpose.

\subsection{Incentives for investment in projects of "non-conventional sources of energy"}

Persons required to declare income to invest directly in such projects, are entitled to reduce their income annually for the five years following the tax year in which they made the investment, fifty percent $(50 \%)$ of the total value of the investment. The value to be deducted for this purpose, in no case may exceed $50 \%$ of the taxpayer's net income determined before subtracting the value of the investment. For the purpose of obtaining this tax benefit, the cause of same investment must be duly certified as such by the Ministry of Environment and be duly certified as such by the Ministry of Environment and Sustainable Development, in accordance with the provisions of Article 158-2 of the Tax Code.

\subsection{Value-added tax incentives}

The energy coming from "non-conventional sources of energy", equipment, components, machinery and national services or imported and intended for preinvestment and investment for the production and use of energy from Conventional Energy Sources and for measurement and evaluation of potential resources are excluded from VAT. To this purpose the Ministry of Environment certify equipment services excluded from the tax, based on a list issued by the Mining and Energy Planning Unit (UPME).

\subsection{Incentive tariff rate}

Natural or legal persons from the enactment of this law; holders of new investments in new projects "non-conventional sources of energy" shall enjoy exemption from payment of import duties on machinery, equipment, materials and supplies work exclusively for pre-investment and investment projects such sources.

\subsection{Accounting incentive, accelerated depreciation of assets}

Generation activities from "non-conventional sources of energy" shall enjoy the status of accelerated depreciation. Accelerated depreciation shall apply to machinery, equipment and civil works necessary for the installation and operation of the generation from "non-conventional sources of energy", which are purchased and/or built exclusively for that purpose, from the force hereof. To 
this end, the annual rate of depreciation will not exceed twenty percent $(20 \%)$ and annual global rate.

\section{Design of the isolated photovoltaic solar system for the communities of Nazareth and Puerto Estrella}

The project under the contract CPS 2013-839, which aims to: "supply equipment, materials, installation and assembly of electrical and civil adjustments to increase power generation capacity and commissioning of substation generation to the districts Nazareth and Puerto Estrella in the municipality of Uribia" (Figure 1 shows the final PV installation), La Guajira. Looking to supply the energy needs of these populations through the use of PV solar energy with two main objectives: increase the hours of electricity supply to the population and reduce the hours of use of diesel plants. To meet the objectives set by the project a diesel-site has been designed that integrates a new solar system with one pre-existing in the hybrid system. The design must meet the demands established in the load curve provided by the IPSE, for which you have to take into account an existing installation and the restrictions imposed by site conditions, geographical location and sustainability and maintenance costs.

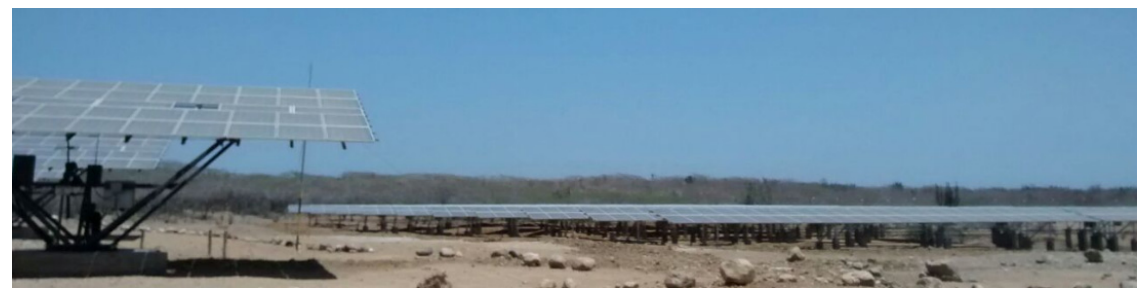

Figure 1: Isolated and hybrid photovoltaic system (solar, storage battery, diesel) for the districts of Nazareth and Puerto Estrella.

\subsection{Preinstalled equipment}

The preinstalled system consists of eight two-axis trackers "Mecasolar 05-08SF" 2009. Each model has 54 solar panels of $230 \mathrm{Wp}$ and three inverters "SMA Sunny Boy SB3800" and a peak power tracker of $12.420 \mathrm{Wp}$; a total of $99.360 \mathrm{Wp}$. It has a main diesel generator of $137 \mathrm{KVA}$. The trackers were not working even in daylight hours because there was no mains either by the generator or batteries; not generated due to non-synchronization. Figure 2 shows the new electric configuration of the solar trackers.

\subsection{Labview simulations}

The energy generated by solar installations during the day will be distributed between the consumption of the population and/or recharging of the batteries in the evening hours, when the batteries reach $70 \%$ capacity; a discharge of $30 \%$, A diesel generator will automatically turn on to begin the process of battery 


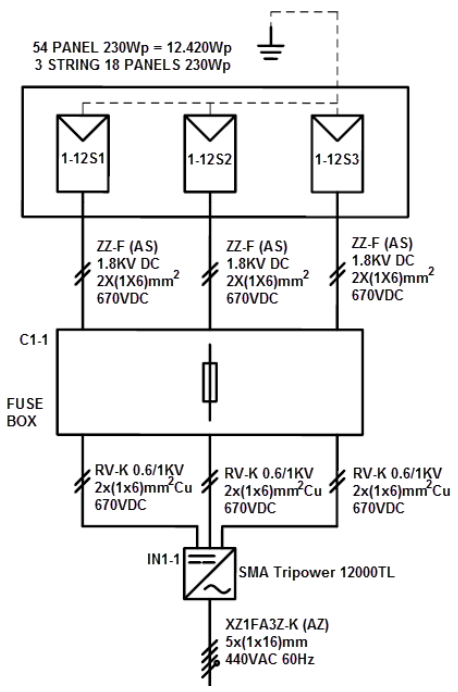

Figure 2: Line diagram of one of the eight solar trackers existing in the installation.

charging up to $100 \%$ and in turn deliver power to consumption. This system may supply 24 hours of electricity services to populations and diesel operating time will be reduced to approximately 10 hours. Then the system was modeled on Labview and simulations to confirm the behavior of the system over time were made. In figure 3 , the daily average cost of diesel is 8.84 hours, while the average period of activation of the diesel generator is 24 hours. With this strategy, the batteries are finished discharging. The limit of battery discharge will occur at 6.00 hours ( 0.25 days), the complete discharge will occur at 198.60 hours (8.28 days). In figure 4, the daily average cost of diesel is 9.83 hours, while the average period of activation of the diesel generator is 24 hours. The system is capable of keeping the batteries charged.

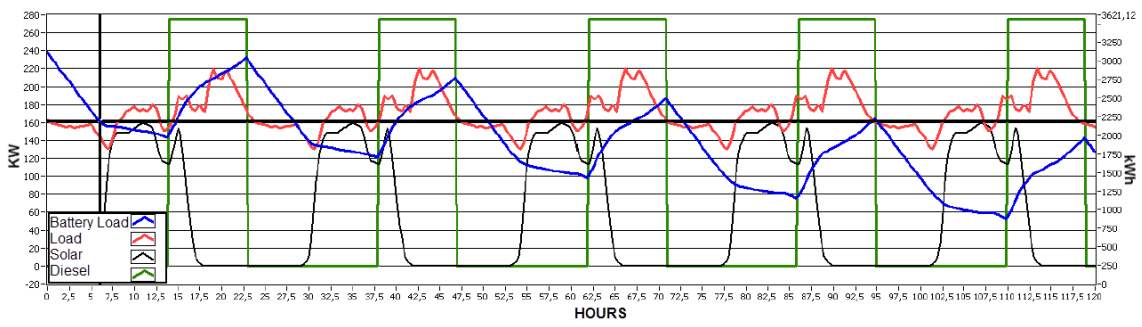

Figure 3: Average radiation with 9 hours of diesel operation (14-23). 


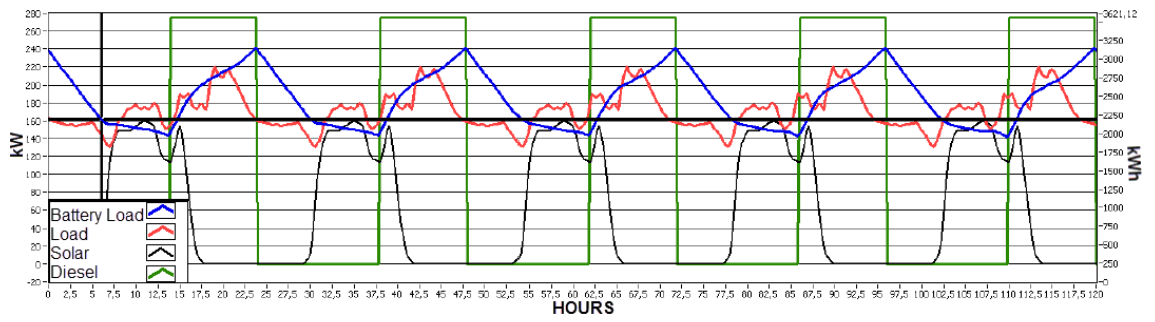

Figure 4: Average radiation with 10 hours of diesel operation (14-24).

\subsection{Design and installation}

The PV generation system comprises a total of 880 polycrystalline solar panels IBC Solar, each of the panels reaches a peak power of $250 \mathrm{~W}$, which will allow the system to provide a total power generation of $220 \mathrm{kWp}$ [8]. Solar panels will be distributed in 20 groups, each group will feature 44 panels connected in series by two strings of 22 panels and a structure of anodized aluminum (Figure 5).

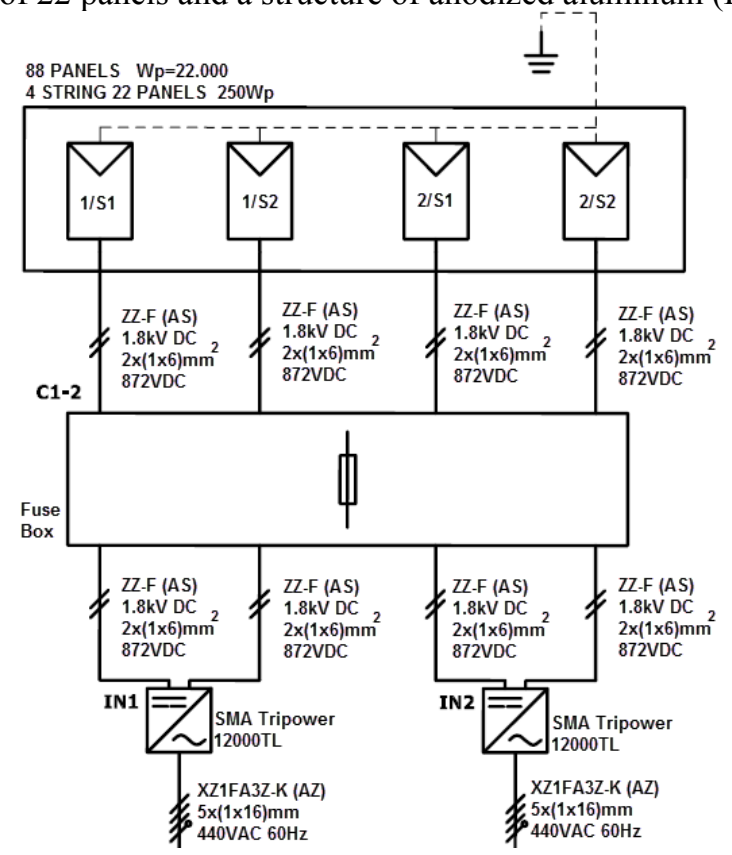

Figure 5: Line diagram - four strings of 22 panels. The photovoltaic system has 10 of these strings.

The structure for each group of panels will be installed in four rows, and shall be oriented to the south at an angle of $10^{\circ}$ (as shown in Figure 6). The structural design was carried jointly with the company Schletter in respect of the axial loads, pressure and wind loads, horizontal loads, and anchor. Module type: PVmax3 1648 x 991mm [9]. 


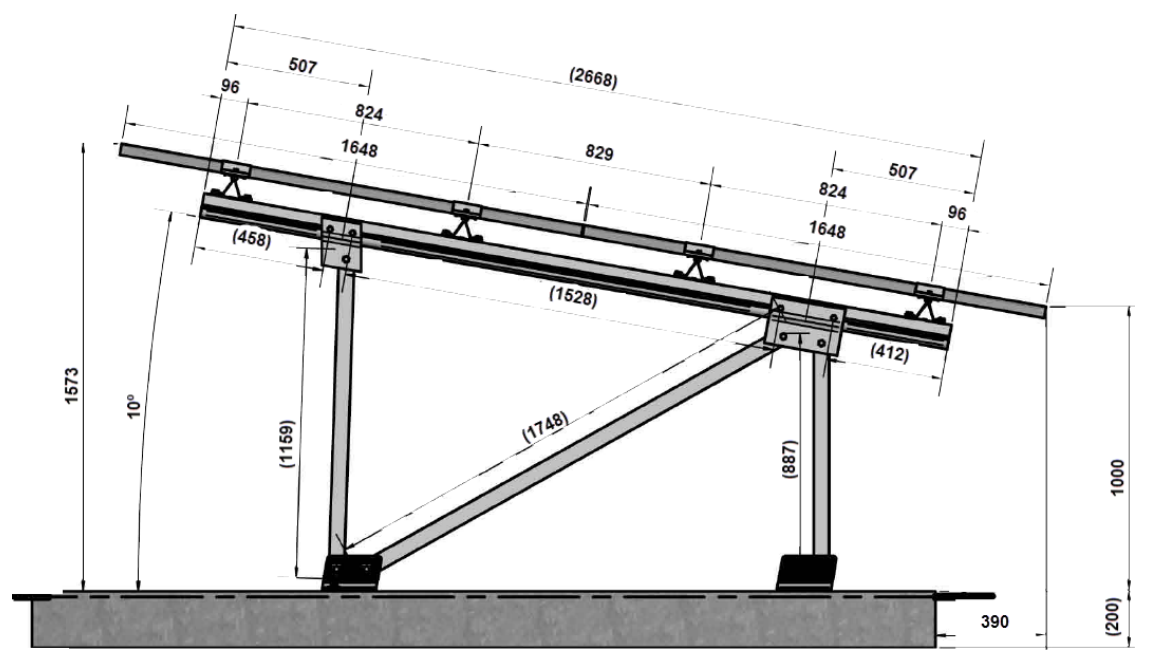

Figure 6: Aluminum module structure type PVmax 3.

They are arranged in two columns of ten rows on the ground. Each group of panels are connected to a grid inverter type Sunny Tripower 12000 TL brand of SMA. They are multi string inverters which convert the direct current of a PV generator into alternating current. To do this, the Sunny Tripower has two trackers of maximum power point (MPPT), which can be connected to different PV modules. Injection of the current grid takes place in three phases. So the total facility will consist of twenty Sunny Tripower DC/AC inverters 12000 TL each connected by a rush to take the tension to the point of protection that will be located in the battery room [10]. The battery room will be the central focus of management of the PV solar facility will be built near the plant and there all the electronic storage and system be housed, it will also have all the security measures and preparation for hosting to all computers. In the battery room, energy production by photovoltaic panels that is obtained enters the "Multicluster Box 36" of the SMA brand. This is a principal distributor of CA to which you can connect up to twelve phase clusters. Each cluster consists of three "Sunny Island" the same type of equipment connected in parallel on the DC side. For this installation ten clusters will be counted (thirty Sunny Island $8.0 \mathrm{H}$ ) which supply the loads AC the isolated grid from the battery or charge the battery with the energy it gets from sources injected into the $\mathrm{AC}$ side. AC sources the isolated grid (e.g. the grid inverter of the PV field) consuming equipment supplied and are used by the inverter grid to recharge the battery. To increase the availability of the isolated grid and reduce the capacity of the battery, the Sunny Island uses and controls external power sources as energy reserves. The Sunny Island supplies consumer teams with active and reactive power. Coupled to each cluster, two banks of batteries are installed, each bank consists of $202 \mathrm{~V}$ cells for a total capacity of $3280 \mathrm{Ah}$ and a voltage of $48 \mathrm{~V}$. In total, twenty batteries will have an installed capacity of $3.148 \mathrm{kWh}$. Each of these elements also has the protections necessary for safe operation, with switches and fuses designed for 
each of them. As an external power supply there are two $308 \mathrm{~kW}$ generators powered by diesel, which are part of the existing installation. Additionally, a dry transformer $(440 / 220 \mathrm{~V} 400 \mathrm{kVA})$ is installed to condition the voltage level that will be available for consumption. The solar PV generation system result of this project, which will provide $220.000 \mathrm{Wp}$ with the solar trackers system is integrated. For this integration it will be necessary replace the Sunny Boy DC/AC inverters SB3800 by Sunny Tripower inverters 12000TL equal to those of the new facility. Figure 7(a) shows a photo of inverter chargers; Figure 7(b) shows the connection wiring diagram.
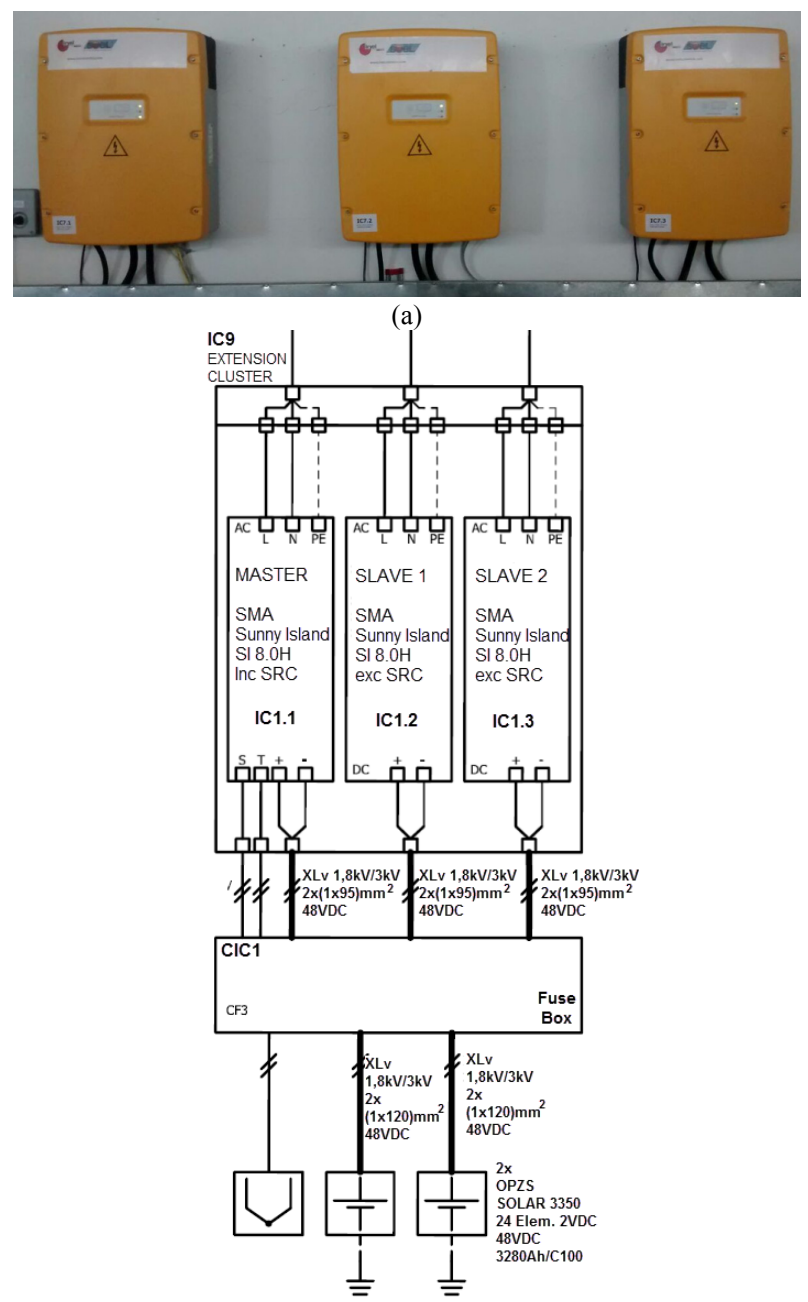

(b)

Figure 7: (a) Extension cluster photo; (b) Line diagram - two batteries of 24 cells of 2VDC. The storage system has 10 of these banks. 


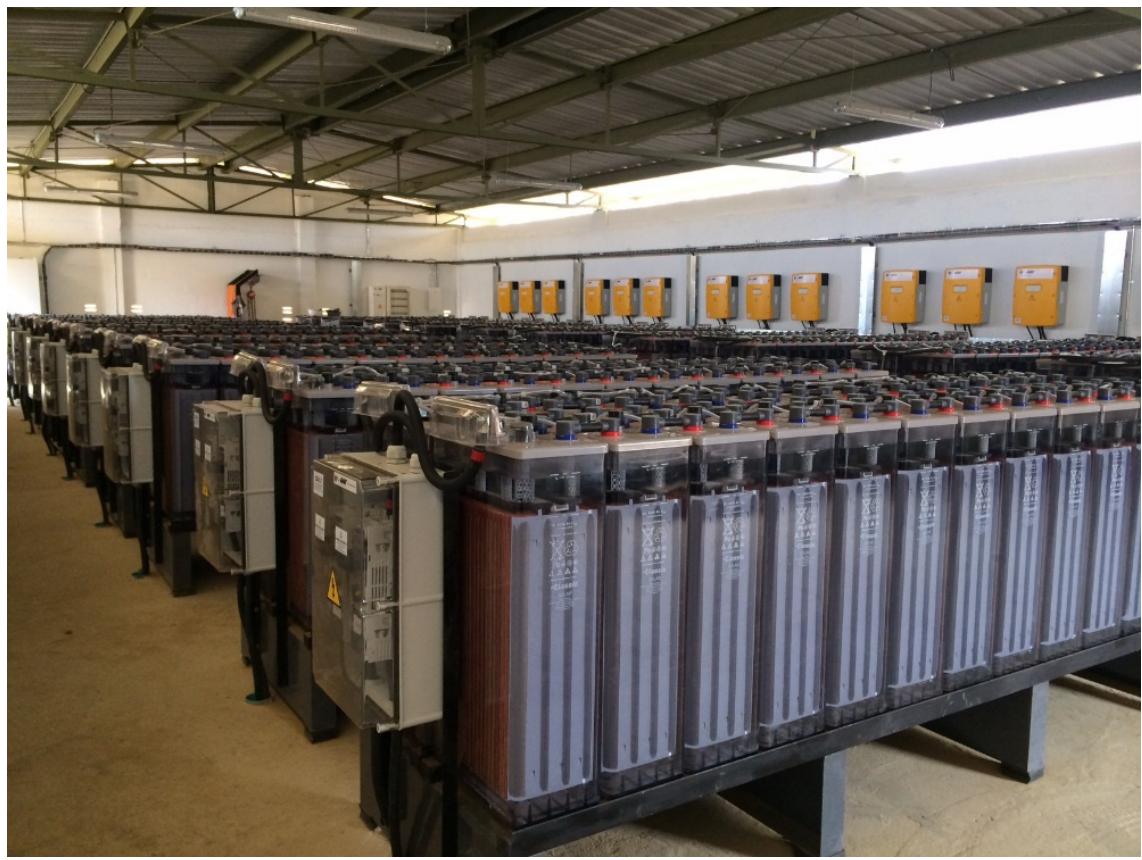

Figure 8: Photo of the battery room, the clusters and multicluster system.

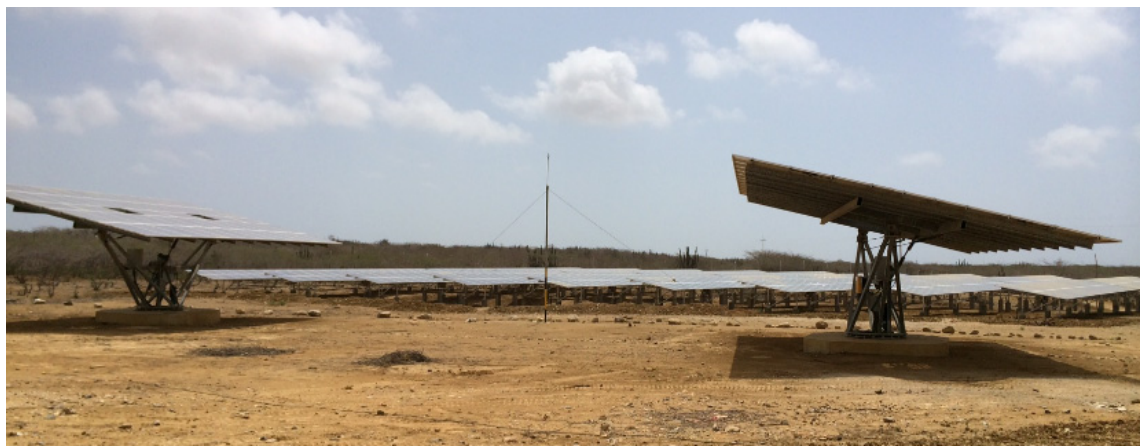

Figure 9: Photo of the isolated photovoltaic installation. View of the solar trackers and fixed installation.

\section{Conclusions}

The main achievement of the project is the use of electrical energy in the community 24 hours a day, in contrast to the 4 hours of the electric service at night before the start of the project. It is also very important that the installed battery allows electrically coupling of the solar trackers in the day to generate 
totally independence of the diesel power plants, apart from workload equalization and leveling in batteries.

The simulations show that it is important for the sustainability of the project to increase installed solar power to supply population demand in peak hours and to recharge batteries in less time with diesel supplement. By increasing $100 \mathrm{kWp}$, the diesel supply can be reduced to four hours.

\section{Acknowledgements}

This work was approved for publication by The Institute of Planning and Promotion of Energy Solutions (IPSE). We thank the Director of IPSE Dr. Gerardo Cañas and the Director of the Consortium that conduct the project Dr. Federico Velez, CEO in Clean Energy Solutions (SUEL).

\section{References}

[1] European Photovoltaic Industry Association, "Global Market Outlook for Photovoltaics 2014-2018,” EPIA, Brussels, 2014.

[2] A. Krulewitz and N. Litvak, "Greentechmedia," 24 January 2014. [Online]. Available: http://www.greentechmedia.com/research/report/ solar-in-latin-america-the-caribbean-2013. [Accessed 01 June 2015].

[3] Congreso Colombiano, Ley N 1715, Bogotá, 2014.

[4] Comisión de Regulación de Energia y Gas, "www.creg.gov.co," 2015. [Online]. Available: http://www.creg.gov.co/. [Accessed 01 June 2015].

[5] Unidad de Planeacion Medio Energetica, "Atlas de Radiacion solar en Colombia," UPME, Bogotá, 2005.

[6] GeoModel Solar, "solargis.info," 2015. [Online]. Available: http://solargis.info/pvplanner/\#tl=Google:hybrid\&bm=satellite. [Accessed 01 June 2015].

[7] IPSE, "www.ipse.gov.co," Instituto de Planificación y Promoción de Soluciones Energéticas para las Zonas No interconectadas, 2015. [Online]. Available: http://www.ipse.gov.co/. [Accessed 01 June 2015].

[8] I. SOLAR, "IBC SOLAR", [Online]. Available: http://solkompaniet.se/ dokument/datablad/IBC_POLYSOL_235_DS_DATASHEET_SOLAR MODULES_EN.pdf. [Accessed 0406 2015].

[9] Schletter, 2015. [Online]. Available: http://www.schletter.us/pvmax.html. [Accessed 0406 2015].

[10] CS. S. T. AG, "SMA", SMA Solar Technology AG, [Online]. Available: http://www.sma.de/en/products/solarinverters/sunny-tripower-5000tl12000tl.html. [Accessed 0406 2015]. 